\title{
Rheological, thermal and mechanical characterization of PBAT/PCL/Stearates
}

\section{blends}

\author{
Caracterização reológica, térmica e mecânica de blendas PBAT/PCL/Estearatos \\ Caracterización reológica, térmica y mecánica de mezclas de PBAT/PCL/Estearatos
}

Received: 02/06/2022 | Reviewed: 02/15/2022 | Accept: 02/23/2022 | Published: 03/04/2022

\author{
Jessé de Melo Silva \\ ORCID: https://orcid.org/0000-0002-0687-4361 \\ Federal University of Campina Grande, Brazil \\ E-mail: jessemello822@gmail.com \\ Fernanda Menezes de Sousa \\ ORCID: https://orcid.org/0000-0002-0208-2666 \\ Federal University of Campina Grande, Brazil \\ E-mail: fernandameneezes@outlook.com \\ Tatiara Gomes de Almeida \\ ORCID: https://orcid.org/0000-0002-2025-2868 \\ Federal University of Campina Grande, Brazil \\ E-mail: tatiaraalmeida@gmail.com \\ Marcelo Augusto Gonçalves Bardi \\ ORCID: https://orcid.org/0000-0001-8740-9172 \\ University São Francisco, Brazil \\ E-mail: marcelo.bardi@bomjesus.br \\ Laura Hecker de Carvalho \\ ORCID: https://orcid.org/0000-0003-3118-0123 \\ Federal University of Campina Grande, Brazil \\ E-mail: heckerdecarvalho@yahoo.com.br
}

\begin{abstract}
The slow degradation and the high environmental impact caused by inappropriate disposal of polymer products are the main factors prompting scientists to either substitute conventional polymers by biodegradable ones or to enhance biodegradation of short-lived polymer products, particularly those used in packaging. Polymer blends of conventional and biodegradable polymers is one of the alternative solutions found to improve mechanical properties and accelerate polymer degradation after disposal. This work investigates the effect of incorporating different metallic stearates $\mathrm{Zn}$ and $\mathrm{Mg}$ ) on the rheological, thermal and mechanical characteristics of 75PBAT/25PCL blends processed in an internal laboratory mixer. The results of torque rheometry suggest degradation during processing potentialized with the stearates incorporation, while that of DSC indicated that the crystallinity of the blends increased with the incorporation of additives. TG data showed a reduction in the thermal stability of the systems containing stearates. Incorporation of stearates resulted in strongly thermally degraded systems. Adding up to $0.25 \%$ of magnesium stearate to the blend 75PBAT/25PCL leads to a material that combines maintenance or improvement of properties combined with higher decomposition.
\end{abstract}

Keywords: PBAT; PCL; Blends; Stearates; Degradation.

\section{Resumo}

A lenta degradação e o alto impacto ambiental causado pelo descarte inadequado de produtos poliméricos são os principais fatores que levam os cientistas a substituir os plásticos convencionais por biodegradáveis ou acelerar a biodegradação de produtos poliméricos de rápido descarte, principalmente aqueles usados em embalagens. Blendas poliméricas a partir de polímeros convencionais e biodegradáveis é uma das alternativas encontradas para melhorar as propriedades mecânicas e acelerar a degradação do polímeros após o descarte. Este trabalho investiga o efeito da incorporação de diferentes estearatos metálicos $(\mathrm{Zn}$ e $\mathrm{Mg})$ nas características reológicas, térmicas e mecânicas de blendas 75PBAT/25PCL processadas em um misturador interno de laboratório. Os resultados da reometria de torque sugerem degradação durante o processamento potencializada com a incorporação de estearatos, enquanto os de DSC indicaram que a cristalinidade das blendas aumentou com a incorporação de aditivos. Os dados de TG mostraram uma redução na estabilidade térmica dos sistemas contendo estearatos. A incorporação de estearatos resultou em sistemas fortemente degradados termicamente. A adição de até $0,25 \%$ de estearato de magnésio à blenda 75PBAT/25PCL resulta em um material que combina manutenção ou melhoria de propriedades combinada com alta decomposição.

Palavras-chave: PBAT; PCL; Blendas; Estearatos; Degradação. 


\begin{abstract}
Resumen
La lenta degradación y el alto impacto ambiental causado por la eliminación inadecuada de los productos poliméricos son los principales factores que impulsan a los científicos a sustituir los plásticos convencionales por otros biodegradables o a mejorar la biodegradación de los productos poliméricos de vida corta, en particular los que se utilizan en los envases. Las mezclas de polímeros de polímeros convencionales y biodegradables son una de las soluciones alternativas encontradas para mejorar las propiedades mecánicas y acelerar la degradación del polímero después de su eliminación. Este trabajo investiga el efecto de la incorporación de diferentes estearatos metálicos ( $\mathrm{Zn}$ y Mg) sobre las características reológicas, térmicas y mecánicas de mezclas 75PBAT/25PCL procesadas en un mezclador interno de laboratorio. Los resultados de la reometría de torque sugieren una degradación durante el procesamiento potencializada con la incorporación de estearatos, mientras que la de DSC indicó que la cristalinidad de las mezclas aumentó con la incorporación de aditivos. Los datos de TG mostraron una reducción en la estabilidad térmica de los sistemas que contenían estearatos. La incorporación de estearatos dio como resultado sistemas fuertemente degradados térmicamente. Agregar hasta un 0,25\% de estearato de magnesio a la mezcla 75PBAT/25PCL conduce a un material que combina el mantenimiento o la mejora de las propiedades con una mayor descomposición.
\end{abstract}

Palabras clave: PBAT; PCL; Mezclas; Estearatos; Degradación.

\title{
1. Introduction
}

Since the end of the 20th century, the search for polymeric materials that can replace polyolefins, maintain their mechanical properties as well as meeting market demands for competitiveness and economic viability, has been a challenge for science (Matta et al., 2018; Godavitarne et al., 2017). As a result, the interest in producing more sustainable products and the search for recyclable and/or less harmful materials to the environment after disposal has increased the use of biodegradable and compostable polymers significantly (Cesario et al., 2018).

Industry, consumers and governments started using these polymers as a potential alternative to reduce the volume of accumulated polymer in the short term in the environment, since these polymers besides being able to be recycled, can be composted and biodegraded in a relatively short time, without the products of its degradation affecting the soil negatively (Kijchavengkul et al., 2010; Avadi et al., 2011).

Poly (butylene-adipate-co-terephthalate) (PBAT) and poly ( $\varepsilon$-caprolactone) (PCL) are biodegradable synthetic polymers, with different physical properties that, under ideal conditions of disposal, are relatively easy to decompose. PBAT is a low-density polymer with high flexibility and resilience, used in the production of plastic bags and foams (Yang et al., 2014). PCL is a biodegradable aliphatic polyester with low melting point and high elasticity (Matta et al., 2014) often used as an additive in order to accelerate degradation of polymer composites and blends. According to Sousa et al. (2018), PCL/PBAT blends are immiscible and show dispersed phase inversion at PCL content around 70\% w/w.

Some authors report the use of different additives, incorporated in polymeric compositions, to improve certain desirable properties for their final application (Konduri et al., 2011; Rosa et al., 2009). As an example, mention is made of the adoption of additives based on metallic stearates, the use of which has been widespread in the industrial environment, due to its characteristics of waterproofing, compatibility, dispersion aids as well as for acting as accelerators of the degradation of polymeric compounds (Antunes et al., 2017).

Cesario et al. (2018), studied the influence of magnesium and cobalt stearates on the properties of PBAT. These metallic stearates $(0.5 \% \mathrm{w} / \mathrm{w})$ were added to PBAT and the compounds have been processed in an internal laboratory mixer. Results showed that the degradation of PBAT increases with the incorporation of stearates. Stearate addition also led to a decrease in mechanical properties of PBAT, particularly for the system containing cobalt stearate. TG analysis showed the PBAT/cobalt system to lose mass at lower temperatures than the other investigated systems, confirming its oxidizing potential. SEM micrographs showed some particles which could be responsible for the observed reduction in ductility of the PBAT compounds.

Rosa et al. (2009) investigated the influence of three different steararates (calcium, cobalt and magnesium) as prooxidant additives in PP, PBAT and their blends. Pristine polymers and their blends with and without stearates were processed in 
a single-screw extruder. Tensile tests showed that thermally pro-oxidized PP/PBAT blends containing cobalt stearate had greater changes in tensile strength when compared to those of similar systems oxidized with calcium or magnesium stearates. In PBAT/PP blends containing pro-oxidants, the incorporation of CoSt resulted in a tensile strength lower than that of neat PP, which suggested a reduction in the interaction between PBAT and PP.

Thus, the objective of this work was to analyze the effect of the incorporation of different metallic stearates (zinc and magnesium) on 75PBAT/25PCL blends based on rheological, thermal and mechanical properties.

\section{Methodology}

\subsection{Materials}

The polymers used were poly (butylene adipate co-terephthalate) (PBAT), purchased from BASF, known commercially as ECOFLEX ${ }^{\circledast}$ FC1200 and PCL (poly- $\varepsilon$-caprolactone), purchased from MCassab and manufactured by PERSTORP under the trade name CAPA $6500^{\circledR}$. The stearates used are based on magnesium and zinc were acquired from ALFA AESAR and can act as lubricants, compatibilizers and pro-oxidants.

\subsection{Sample processing}

Samples of neat PBAT, PCL, and PBAT/PCL blends, added with $0.125 \%$ and $0.250 \% \mathrm{w} / \mathrm{w}$ of each of the stearates, were prepared in a Thermo Scientific OS torque rheometer operating with an internal mixer accessory (Rheomix 3000) with $70 \%$ fill factor, roller type rotors, at $60 \mathrm{rpm}$ and $200^{\circ} \mathrm{C}$ chamber wall temperature, for 15 minutes. The samples were ground and fed to a 16-mm bench scale single screw extruder Lab-16 Chill-Roll from AX Plásticos (Brazil) fitted with a flat die, operating in a temperature range of 120 to $180^{\circ} \mathrm{C}$ and $35-45 \mathrm{rpm}$, to prepare films for further characterization. Films specimens with thickness between 112 and $211 \mu \mathrm{m}$ were obtained.

\subsection{Rheological characterization}

In this work, the internal mixer Haake Rheomix 3000 was used for the preparation of 100\% PBAT, blends 3:1 PBAT/PCL and 100\% PCL, coded as: PBAT and 75PBAT/25PCL blend and PCL. Where, PCL and PBAT correspond, respectively, to neat polycaprolactone and poly (butylene adipate-co-terephthalate), processed under the same conditions as the blends.

The methodology used in the characterization by torque rheometry used in this work is based on the models developed by Canedo and Alves (2015) and Alves et al. (2016) and applied to the study of polymer additives, blends and polymer matrix composites (Costa et al., 2015; Duarte et al., 2016; Almeida et al., 2016; Marinho et al. 2017). The internal laboratory mixer registers the melt temperature $\left({ }^{\circ} \mathrm{C}\right)$ inside the processing chamber and the torque $[Z(\mathrm{Nm})]$ as functions of time $[t(\min )]$; and measurements are taken at a ratio of 10 points per minute. The analysis of $T(t)$ e $Z(t)$ during the last stage of processing (melt processing) allows to estimate the rheological characteristics (viscosity dependence with temperature and shear rate) of the processed material and to study incipient degradation during processing.

\subsection{Degradation during processing}

Viscosity, and hence torque, are dependent on molar mass and temperature. For a given polymer melt with pseudoplasticity index n, processed at constant temperature (Alves et al., 2016; Canedo, 2017) viscosity is given by:

$$
\eta \propto M_{w}^{2,5+n}
$$


During processing in an internal mixer, the melt temperature often differs from that of the chamber walls due to attrition. If the polymer is thermally stable and does not degrade during processing, melt temperature will reach a constant value. If the polymer is not thermally stable, polymer melt temperature with either increase if the dominant reactions are cross-linking or decrease if chain scission predominates. Consequently, torque variation at the final stages of processing is associated with the combined effects of changes in melt temperature and in polymer molar mass. In order compare the effect of composition on torque for different polymer systems one must eliminate the effect of temperature on viscosity, and therefore on torque. This is done by using the concept of adjusted torque, i.e., the torque estimated at a given reference temperature, given by:

$$
Z^{*}=Z \exp \left\{\beta\left(T-T^{*}\right)\right\}
$$

Where $Z^{*}$ is the torque adjusted to the reference temperature $T^{*}\left(200^{\circ} \mathrm{C}\right) . \beta$ is the exponential temperature coefficient of the material which was determined to be $\beta \approx 0.017^{\circ} \mathrm{C}^{-1}$ for PCL $\beta \approx 0.025^{\circ} \mathrm{C}^{-1}$ for PBAT and $\beta \approx 0.014{ }^{\circ} \mathrm{C}^{-1}$ for the PBAT/PCL blends, regardless of composition (Sousa et al., 2018; Reul et al., 2018; Sousa et al., 2016).

The rate of degradation during the last processing stage was estimated as a function of composition processing conditions, for all systems investigated, from the adjusted average torque and the rate of change of the adjusted torque as:

$$
\begin{aligned}
& R_{Z}=-\frac{1}{\overline{Z^{*}}} \frac{d Z^{*}}{d t} \\
& R_{M}=\frac{1}{2,5 n+1} R_{Z}
\end{aligned}
$$

where $\mathrm{R}_{\mathrm{Z}}$ and $\mathrm{R}_{\mathrm{M}}$ are, respectively, the rates of change of the adjusted torque and the weight average molar mass of the material (Canedo, 2017) and $n$ is the pseudoplasticity index of the material which for PCL, PBAT and the PBAT/PCL blends were determined to be $0.94 ; 0.60$ and 0.59, respectively (Sousa et al., 2018; Reul et al., 2018; Sousa et al., 2016).

If time is expressed in minutes, $100 \mathrm{R}_{\mathrm{M}}$ is the " $\%$ variation of the average weight molar mass per minute of processing".

\subsection{Infrared Spectroscopy (FTIR)}

FTIR analyzes were performed on the samples obtained aiming to detect the degradation of the systems by means of the carbonyl indices, accomplished by monitoring the ratio of the absorption bands at $2854-2834 \mathrm{~cm}^{-1}$ (reference) and at 1740 $1720 \mathrm{~cm}^{-1}$. The analyzes were conducted on a Nicolet spectrometer, model AVATAR TM 360 ESP operating with a scan of 4000 to $400 \mathrm{~cm}^{-1}$.

\subsection{X-ray diffraction $(D R X)$}

Blends containing zinc and magnesium stearate were characterized by X-ray diffraction (XRD). The analyzes were conducted at room temperature in a XDR-6000 model Shimadzu diffractometer, using copper K $\alpha$ radiation as an incident source, with a wavelength $\lambda=0.154 \mathrm{~nm}$. The data were collected in a $2 \theta$ angular range from $2^{\circ}$ to $30^{\circ}$, at a scanning speed of $1 \% \mathrm{~min}$. 


\subsection{Differential Scanning Calorimetry (DSC)}

DSC tests were performed on the TA DSC Q20 equipment, with samples weighting between 7 and $8 \mathrm{mg}$, in a closed and perforated aluminum crucible, under nitrogen flow of $50 \mathrm{~mL} / \mathrm{min}$. A three-stage temperature program was used: heating from $25^{\circ} \mathrm{C}$ to $250^{\circ} \mathrm{C}$ at $20^{\circ} \mathrm{C} / \mathrm{min}$; cooling from $250^{\circ} \mathrm{C}$ to $-25^{\circ} \mathrm{C}$ at $10^{\circ} \mathrm{C} / \mathrm{min}$; and reheating from $-25^{\circ} \mathrm{C}$ to $250^{\circ} \mathrm{C}$ at $10^{\circ} \mathrm{C} / \mathrm{min}$.

\subsection{Thermogravimetric Analysis (TGA)}

Thermogravimetric analyzes of PCL, PBAT and blends, with and without the incorporation of stearates, were performed in SHIMADZU equipment, model DTG-60H, under nitrogen atmosphere (flow:100 mL/min) with samples weighting approximately $5 \mathrm{mg}$. The samples were heated at a heating rate of $10^{\circ} \mathrm{C} / \mathrm{min}$ from 0 to $600^{\circ} \mathrm{C}$.

\subsection{Tensile Properties}

Film specimens were tensile tested according to ASTM D882, in an EMIC DL1000 universal testing machine fitted with a $20 \mathrm{~N}$ load cell operating at $50 \mathrm{~mm} / \mathrm{min}$ extension rate at ambient temperature. Young's modulus was estimated from the slope of the initial linear region of the stress $\mathrm{x}$ strain curve. The maximum tensile strength was determined by dividing the maximum tensile load carried by the specimen during the test by the original sample cross-sectional area.

\subsection{Scanning electron microscopy (SEM)}

Scanning electron microscopy images of gold sputtered surfaces were obtained in a Tescan Vega3 equipment with of $5 \times-5000 \times$ magnification.

\section{Results and Discussion}

\subsection{Torque Rheometry}

Figure 1 shows the torque and temperature curves versus time for the neat 75PBAT/25PCL blend and containing $0.125 \%$ and $0.250 \%$ of zinc and magnesium stearates.

The torque and temperature curves, for all samples, show similar behavior. Initially there is a rapid increase in torque generated by the dissipation of mechanical energy in particulate solids, when material is being fed into the chamber, until reaching a maximum and decreasing with the drop in viscosity due to polymer melting. Torque decreases over time but does not reach a stable plateau. After 8 minutes of processing, the blend is considered to be substantially melted. The temperature drops with the opening of the chamber and introduction of the inputs, and increases with time as the polymer heats up and melts, tending to stabilize and reach a plateau after 8 minutes of processing. The data obtained demonstrate that both torque and temperature decrease with the addition of stearates in the 75PBAT/25PCL blend. The drop is more pronounced for blends containing magnesium, and in systems with a higher content of any of the stearates. 
Figure 1 - Temperature curves (a) and torque (b) as a function of time for 75PBAT/25PCL neat blend and containing 0.125\% and $0.250 \%$ of zinc and magnesium stearates.
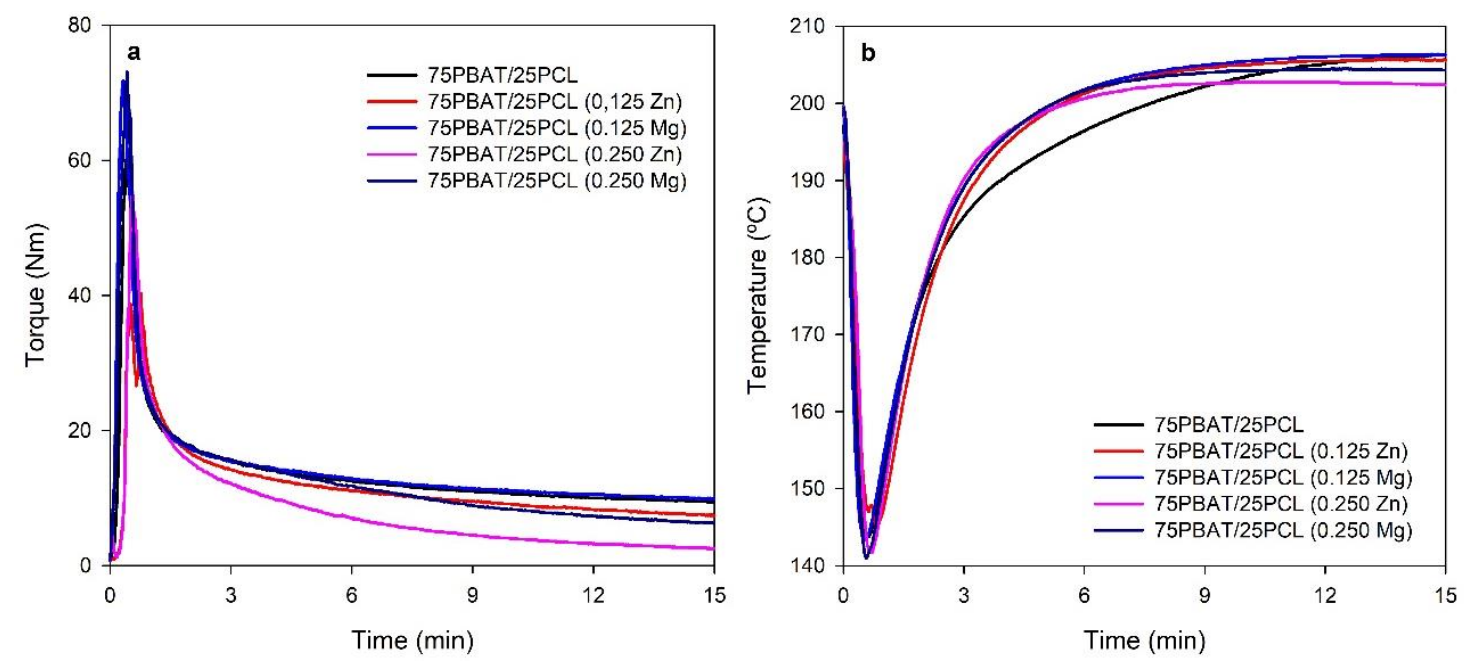

Source: Authors.

Figure 2 is an enlargement of Figure 1 at the final stage of processing and shows the evolution of torque and temperature in the time interval between 10-15 minutes for all samples tested.

Figure 2 - Temperature curves (a) and torque (b) as a function of time for 75PBAT/25PCL neat blend and containing $0.125 \%$ and $0.250 \%$ of zinc and magnesium stearates in the 10-15 minutes interval.
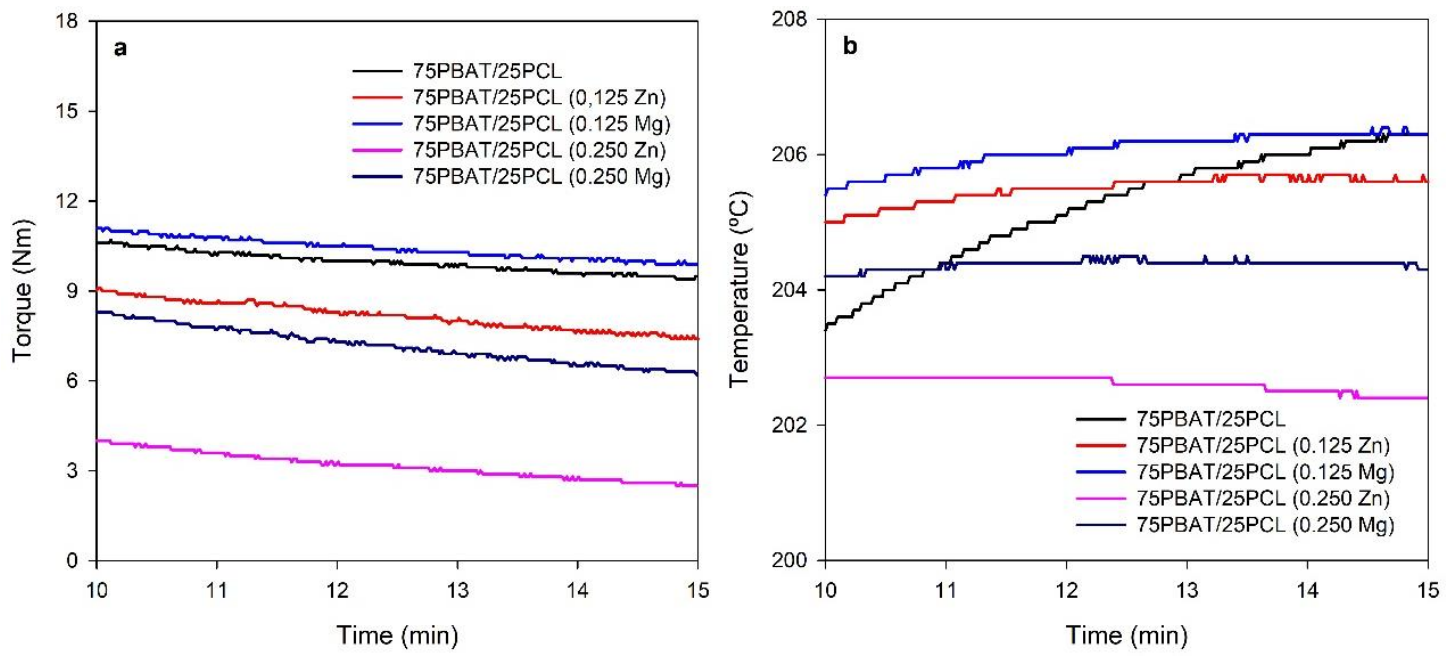

Source: Authors.

In the last 5 minutes of processing there is an evident reduction in torque (better perceived in the blend containing $0.250 \%$ zinc stearate) and a slight increase in temperature (better noticed in blends without stearate) for neat blends and blends with $0.125 \%$ stearates. Blends containing $0.250 \%$ of stearates reach a stable temperature plateau in the final processing interval. The results also show that, except for the blend containing $0.125 \%$ magnesium stearate, both torque and temperature of the 75PBAT/25PCL blend is higher than of those containing stearates. Torque and temperature in the final stages of processing are lower the greater the concentration of stearate incorporated. The non-stabilization of torque is taken as an indication that there blend degradation occurred under the processing conditions adopted in this work. 
Figure 3 shows the adjusted torque at $200^{\circ} \mathrm{C}$ as a function of time in the last 3 minutes of processing, for all samples tested and indicates that the adjusted torque decreases with time, for all compositions. Table 1 presents the calculated parameters in the final interval of processing (12-15 min). These include, respectively, the average temperature and adjusted torque in that range $\left(\bar{T}\right.$ and $\left.\overline{Z^{*}}\right)$ and two versions of the degradation rate: the relative rate of reduction of the adjusted torque $\left(\mathrm{R}_{\mathrm{Z}}\right)$ and the relative rate of reduction of weight average molar mass $\left(\mathrm{R}_{\mathrm{M}}\right)$, evaluated according to the procedure described in the experimental section.

Figure 3 - Adjusted torque at $200^{\circ} \mathrm{C}$ as a function of time for $75 \mathrm{PBAT} / 25 \mathrm{PCL}$ neat blend and containing $0.125 \%$ and $0.250 \%$ of zinc and magnesium stearates in the 12-15 minutes interval.

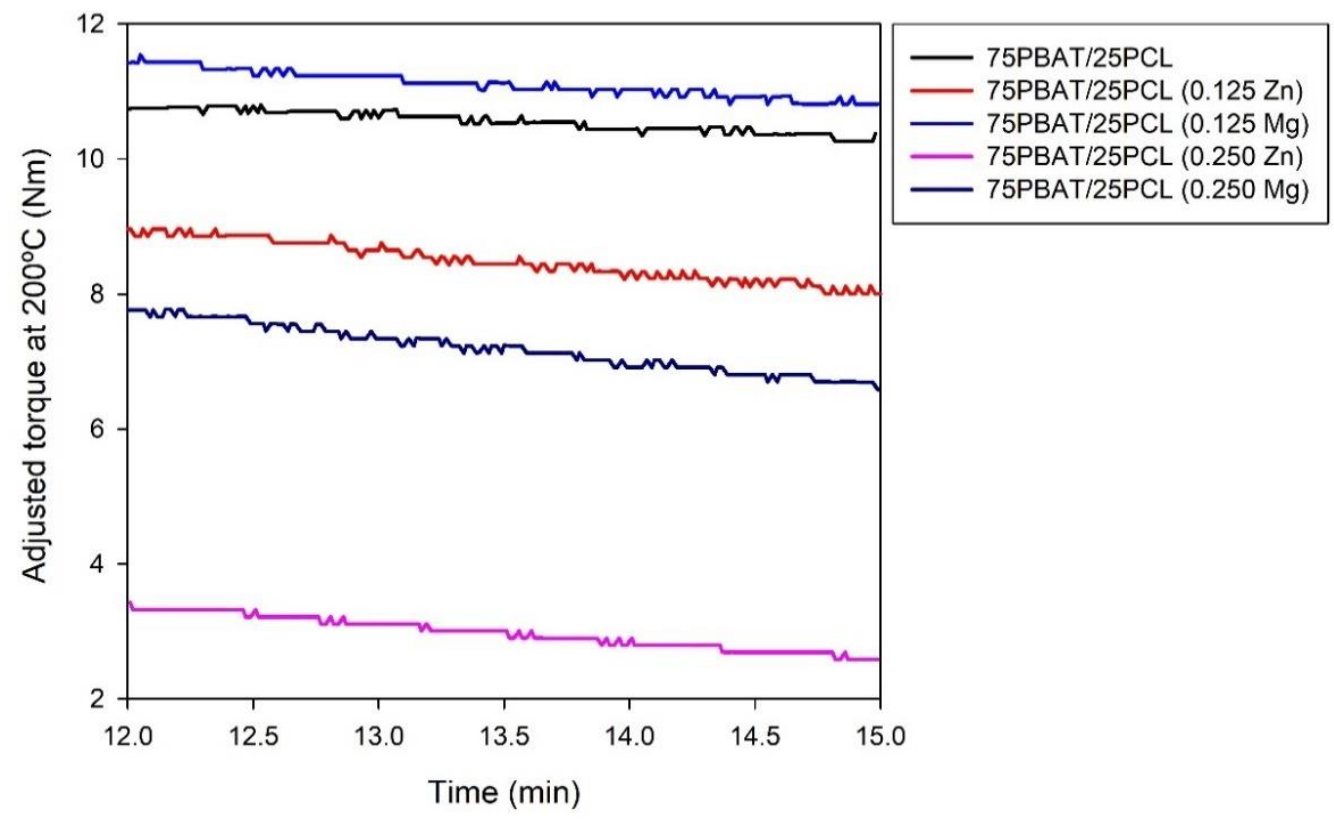

Source: Authors.

Table 1 - Final processing parameters for 75PBAT/25PCL neat blend and containing $0.125 \%$ and $0.250 \%$ of zinc and magnesium stearates at $200^{\circ} \mathrm{C}$.

\begin{tabular}{lcccc}
\hline \multicolumn{1}{c}{ Sample } & $\bar{T}$ & $\overline{Z^{*}}$ & $-R_{Z}$ & $-R_{\mathrm{M}}$ \\
& $\left({ }^{\circ} \mathrm{C}\right)$ & $(\mathrm{Nm})$ & $\left(\mathrm{min}^{-1}\right)$ & $\left(\mathrm{min}^{-1}\right)$ \\
\hline 75PBAT/25PCL & $205.8 \pm 0.30$ & $10.6 \pm 0.15$ & -0.0160 & -0.0052 \\
75PBAT/25PCL (0.125 Zn) & $205.6 \pm 0.06$ & $8.5 \pm 0.28$ & -0.0379 & -0.0123 \\
75PBAT/25PCL (0.125 Mg) & $206.2 \pm 0.08$ & $11.1 \pm 0.19$ & -0.0190 & -0.0061 \\
75PBAT/25PCL (0.250 Zn) & $202.5 \pm 0.09$ & $3.0 \pm 0.23$ & -0.0902 & -0.0291 \\
75PBAT/25PCL (0.250 Mg) & $204.4 \pm 0.04$ & $7.2 \pm 0.33$ & -0.0529 & -0.0171 \\
\hline
\end{tabular}

Source: Authors.

The results reported in Table 1 show that the blends containing $0.125 \% \mathrm{Zn}$ and $\mathrm{Mg}$ stearates showed reductions of $3.8 \%$ and $1.9 \% / \mathrm{min}$, respectively, in their adjusted torque variation rate, while the blend without stearate showed a reduction of $1.6 \% / \mathrm{min}$. For blends containing $0.250 \%$ stearates the reductions were $9.0 \%$ and $5.3 \% / \mathrm{min}$, for blends containing $\mathrm{Zn}$ and $\mathrm{Mg}$, respectively. These results show that the addition of stearates to the PBAT/PCL blend increases the degradation of these systems, 
and that this degradation is more intense with increasing contents of stearates in the blend. For the same stearate content, the degrading action with the zinc additive is superior to that of the magnesium additive.

Analyzing the mean adjusted torque values, for concentrations of $0.125 \%$ of zinc stearate and $0.250 \%$ of any of the stearates used, the degrading effect of the additive predominates, promoting a reduction in torque throughout the final period of time studied. For the 75PBAT/25PCL blend containing $0.125 \mathrm{Mg}$ stearate there was an increase in average torque compared to the neat blend, indicating that, for this concentration, magnesium stearate may have acted as a lubricant, minimizing the degradation of the blend. The results highlight the 75PBAT/25PCL formulation containing $0.125 \mathrm{Mg}$ stearate as the best composition in the studied range, since this formulation presented the best processing conditions (lower torque and temperature) and, according to torque analysis, less degradation.

\subsection{Fourier Transform Infrared Spectroscopy (FTIR)}

Figure 4 shows the FTIR spectrum obtained for blends.

Figure 4 - Infrared spectrum of 75PBAT/25PCL neat blend and containing $0.125 \%$ and $0.250 \%$ of zinc and magnesium stearates.

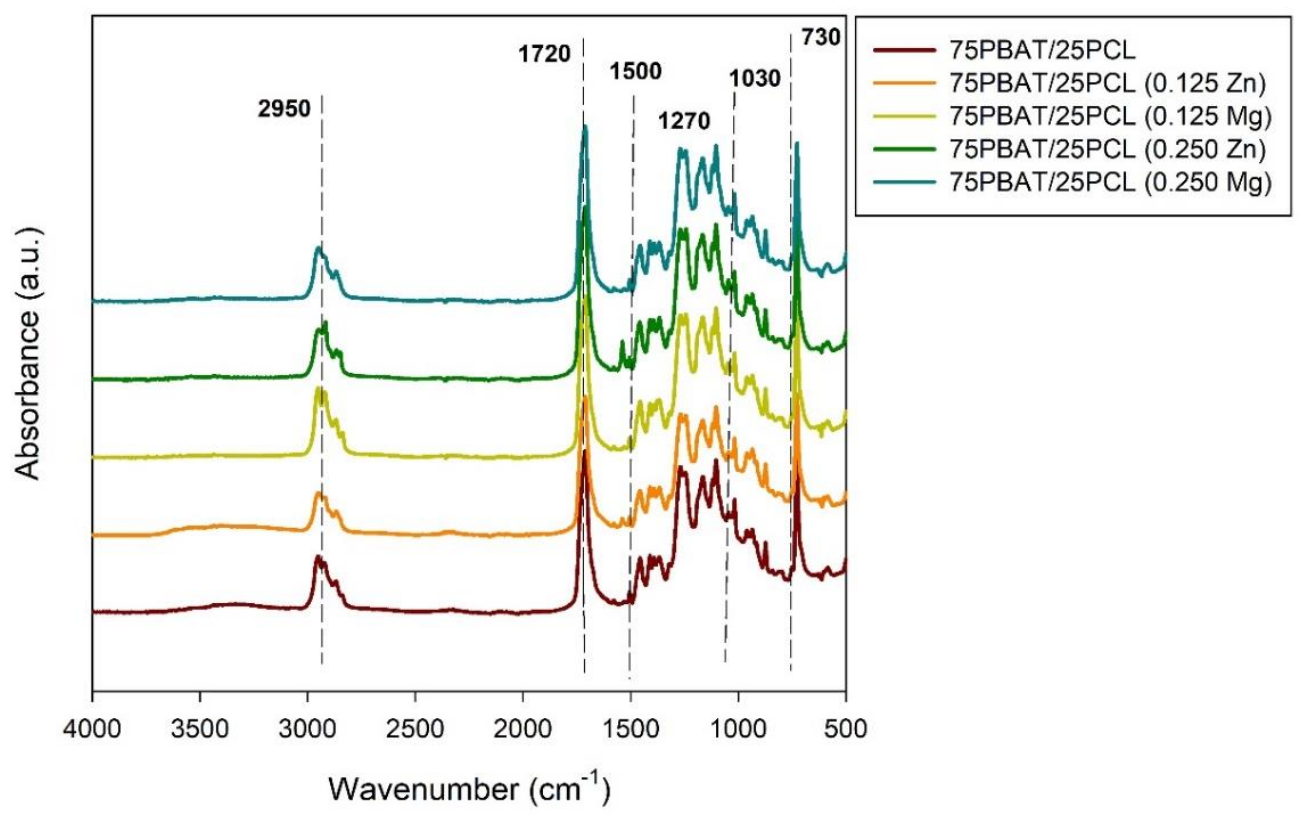

Source: Authors.

The spectra obtained are very similar, showing little difference in peak intensity. All samples showed common vibrational stretches related to the asymmetric stretching of the C-H groups, in $2950 \mathrm{~cm}^{-1}$ (Almeida, 2019; Cesario, 2019; $\mathrm{Wu}$, 2012). An intense peak was observed at approximately $1720 \mathrm{~cm}^{-1}$ corresponding to the vibration of the carbonyl $(\mathrm{C}=\mathrm{O})$ of the ester group. Other peaks related to stretching in the CO group were observed at approximately $1503 \mathrm{~cm}^{-1}$ and at $1270 \mathrm{~cm}^{-1}$, as previously reported (Almeida, 2019; Cesario, 2019; Wu, 2012; Pagno et al., 2020; Bheemaneni et al.), typical of the investigated stearates. Absorption bands at approximately $1030 \mathrm{~cm}^{-1}$ have been attributed to the angular deformation of the C-H bonds (Almeida, 2019; Stuart, 2005). The peak at $730 \mathrm{~cm}^{-1}$ characterizes the flexion vibration of $\mathrm{CH}$ in the plane of the aromatic ring of saturated compounds in the angular deformation region of the group $-\left(\mathrm{CH}_{2}\right)_{2}-$ and the group $-\left(\mathrm{CH}_{2}\right)_{\mathrm{n}}-$ for $\mathrm{n}>4$ and still absence of absorption related to the stretching of the $\mathrm{C}-\mathrm{O}-\mathrm{C}$ group, as the oxygen in the group is bound to a carbon and to the metallic ion (Mg, Zn) which characterizes the presence of salt (Cesario, 2019; Roy et al., 2006; Gönen et al., 2015). 


\subsection{X-Ray Diffraction (XRD)}

Diffraction peaks of the investigated systems are shown in Figure 5.

Figure 5 - Diffraction peaks of 75PBAT/25PCL neat blend (a) and containing $0.125 \%$ and $0.250 \%$ of zinc (b) and magnesium (c) stearates.
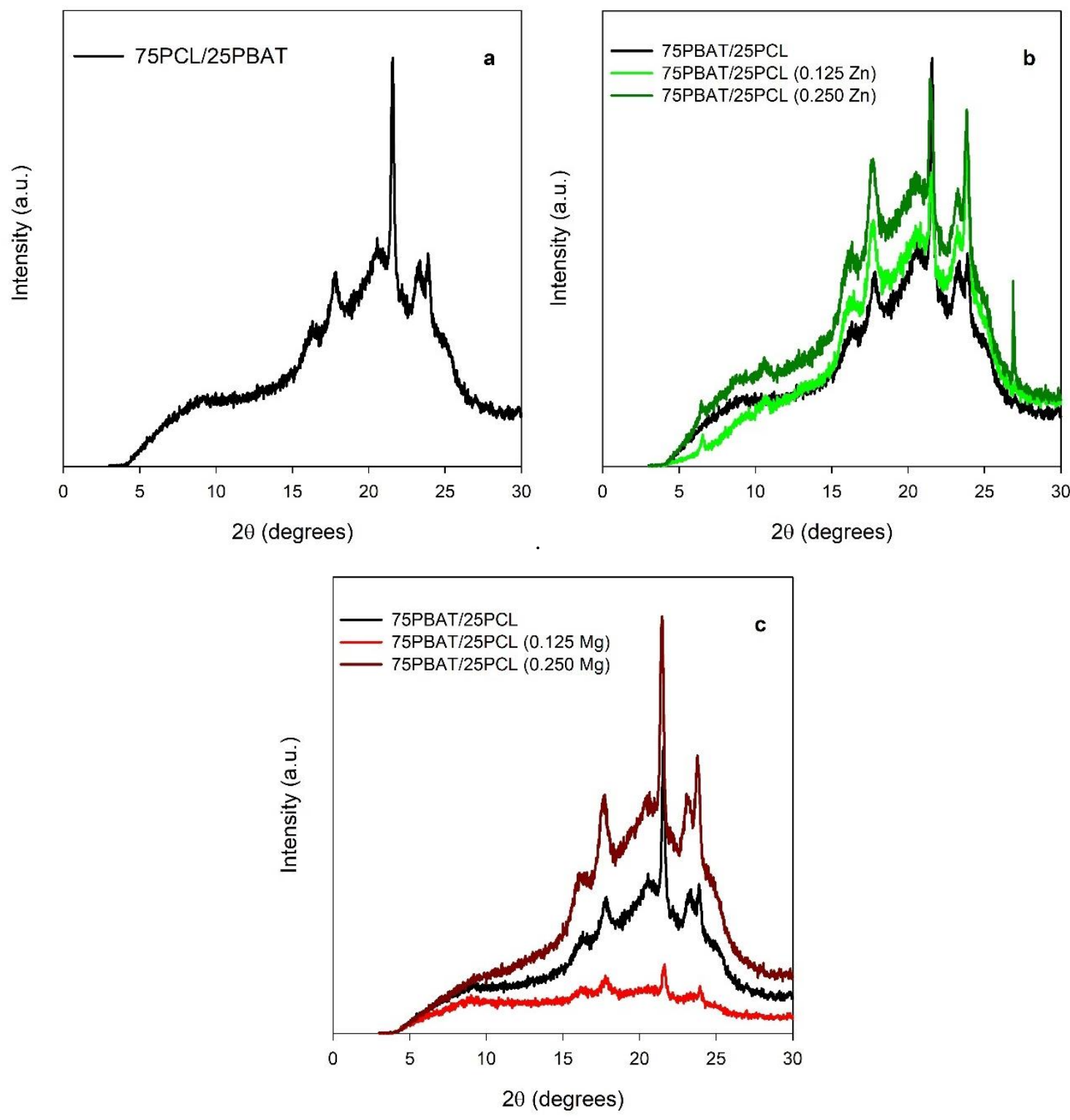

Source: Authors.

Evaluating the diffractogram of the neat 75PBAT/25PCL blend, it was possible to observe peaks in $2 \theta$ equal to $17.5^{\circ}$ (010); $20.4^{\circ}$ (101); and 24.1 ${ }^{\circ}$ (111), referring to the PBAT. Regarding the PCL, whose unit cell has an orthorhombic crystalline form, it was observed that this organization leads to the emergence of a crystalline reflection peak, which appears centered at $2 \theta=23.4^{\circ}$, which corresponds to the crystalline plane (110) of the orthorhombic crystal (Miyata \& Masuko, 1997; Cavalcante, Rodrigues \& Tavares, 2015). Similar diffractograms were obtained for blends containing with stearates, where it was possible to observe the increase in crystallinity through changes in the peaks of the additived systems, that became more intense and narrower, especially for the blend with zinc stearate, different from the neat blend, that presents larger and less intense peaks. According to Kijchavengkul et al. (2010), the increase in crystallinity may be caused by degradation, as the amorphous zones of 
the system are more easily attacked, reducing the molar mass, acquiring greater mobility and, consequently, better crystallizing the polymer.

\subsection{Differential Scanning Calorimetry (DSC)}

Figure 6 shows the plot of heat flow versus time during the cooling and reheating temperature stages for all samples studied.

Figure 6 - Heat flow versus time for 75PBAT/25PCL neat blend and containing $0.125 \%$ and $0.250 \%$ of zinc and magnesium stearates (exothermic peaks up).

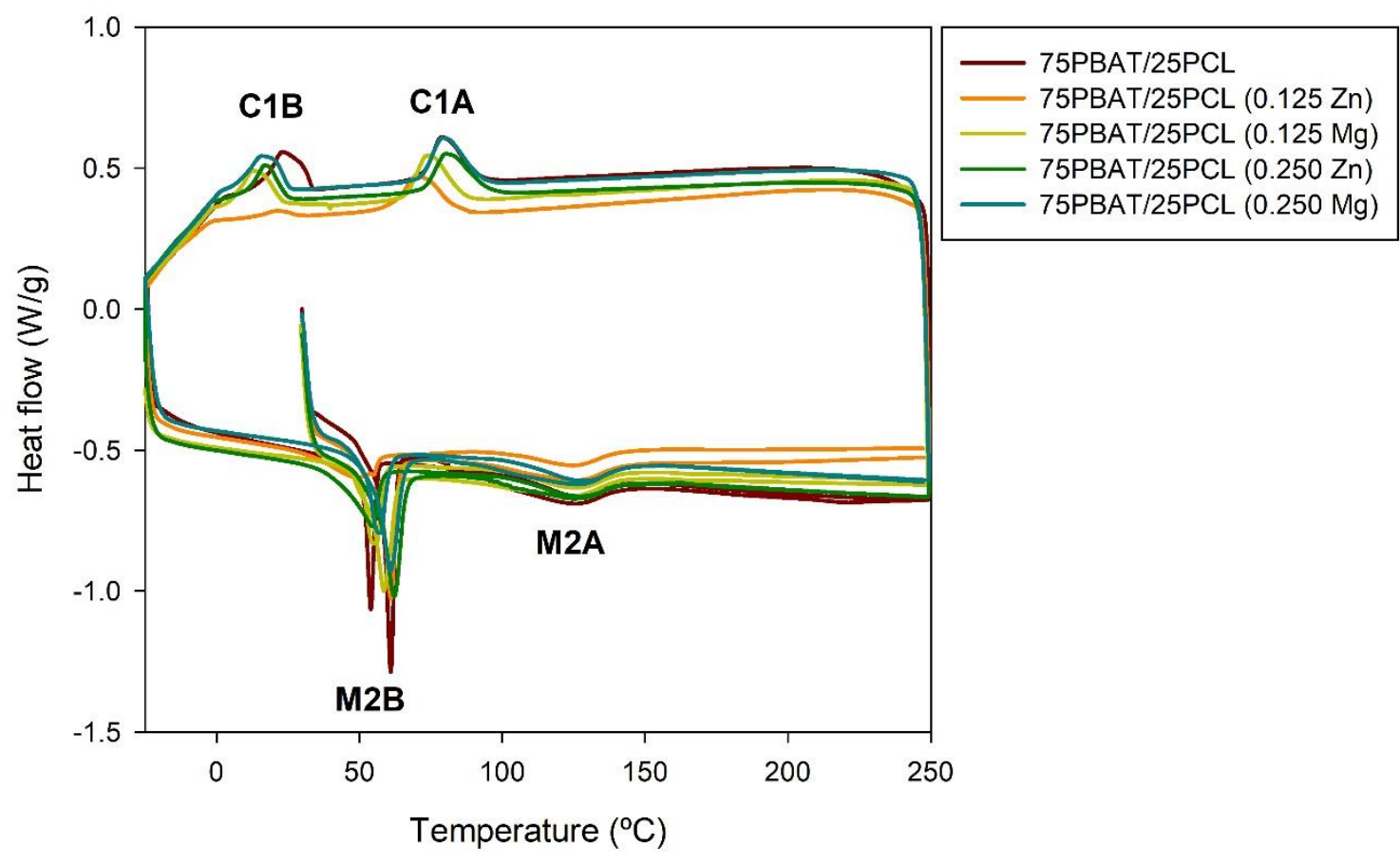

Source: Authors.

In all studied samples single crystallization melting peaks (C1) were observed during the cooling stage with separate crystallization peaks for PBAT (C1A) and PCL (C1B). Upon reheating, melting peaks (M2) with a shallow melt-related peak for PBAT (M2A) and a sharp and deep peak related to PCL melting (M2B). To determine several transition parameters, crystallization and melting during reheating peaks were analyzed in detail.

\subsubsection{Crystallization event}

Figure 7 illustrates characteristic parameters of the crystallization event for all samples studied: peak crystallization temperature and relative crystallinity. 
Figure 7 - Peak crystallization temperature (a) and crystallinity (b) for 75PBAT/25PCL neat blend and containing 0.125\% and $0.250 \%$ of zinc and magnesium stearates.
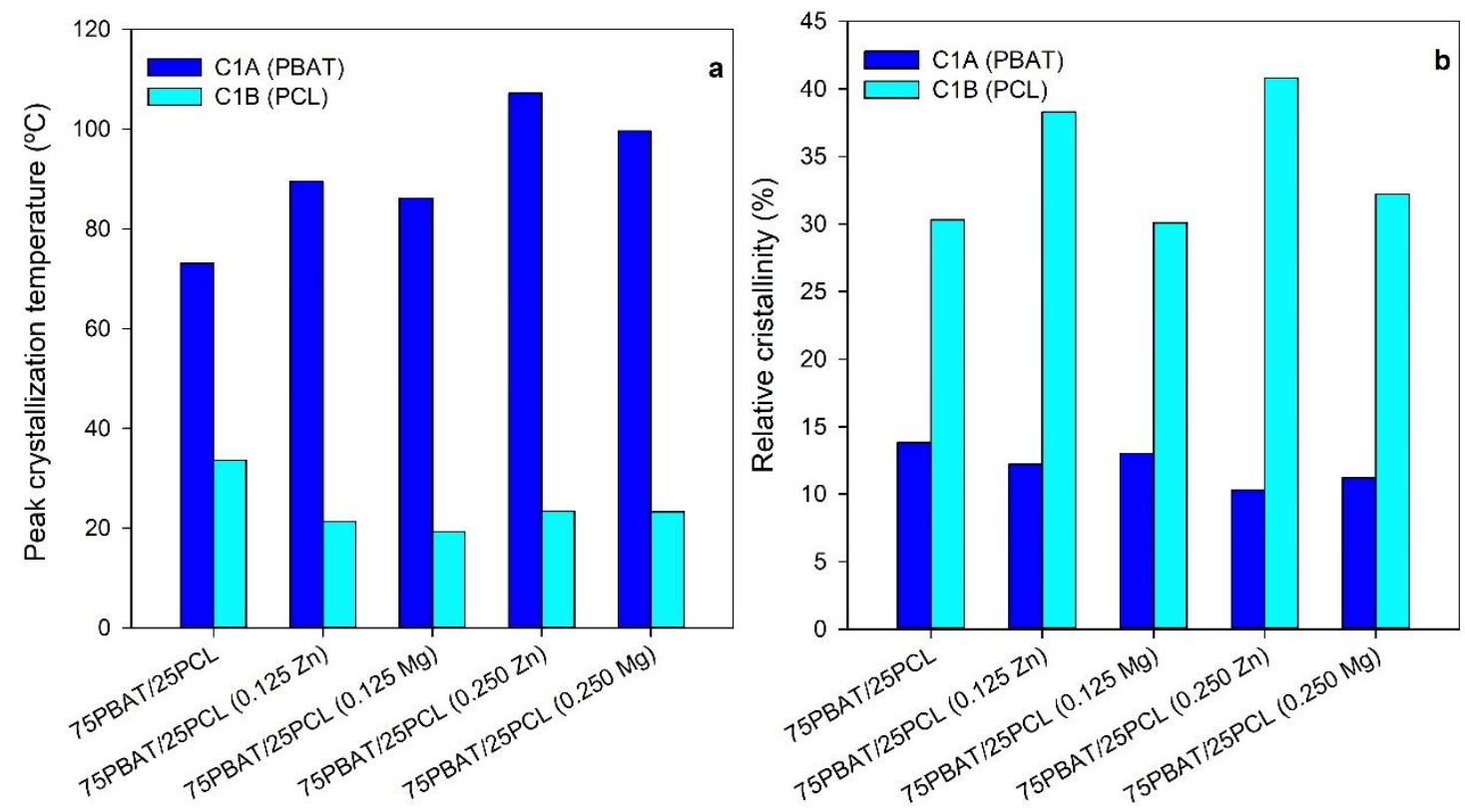

Source: Authors.

Figure 7a shows that, compared to neat blends, the presence of stearates led to an increase in the crystallization peak temperature of PBAT in the blend. The maximum increase was $34.1^{\circ} \mathrm{C}$ for the blend containing $0.250 \%$ zinc stearate. The incorporation of stearates to the 75PBAT/25PCL blend causes a decrease in the PCL crystallization temperature, which is more significant in the blend containing $0.125 \%$ of magnesium stearate, with a decrease of $14.3^{\circ} \mathrm{C}$, when compared to the neat blend.

In blends containing $0.125 \%$ of stearates there was no significant change in the degree of crystallinity of PBAT (Figure 7b). However, the blends with $0.250 \%$ of stearates suffered slight decreases in crystallinity, when compared to the neat blend. The blend containing $0.250 \%$ of zinc stearate was again the most affected, showing a loss of $3.5 \%$ of crystallinity when compared to the neat 75PBAT/25PCL blend. The data show that the stearates tends to increase the degree of crystallinity of the PCL in the blends, reaching up to $40.8 \%$ of crystallinity for the blend containing $0.250 \%$ of zinc stearate. The crystallization temperature of PBAT increased, increases the number of kernels in the polymer, and decreasing the size of the spherulite. The additives acted as nucleating agents.

\subsubsection{Melting event}

Figure 8 illustrates characteristic parameters of the melting event for all samples studied: peak melting temperature and relative crystallinity.

Figure 8a indicates that the addition of stearates to the 75PBAT/25PCL blend caused an increase in the melting peak temperature of PBAT in all samples. As to PCL, the addition of stearates did not change the melting peak temperature in the blends. Regarding to the degree of crystallinity, it was observed that it tends to decrease for PBAT, reaching only $3.4 \%$, for the blend containing $0.250 \%$ of zinc stearate. However, the degree of crystallinity of PCL tends to increase with increasing stearate content in the blend. The blend with $0.250 \%$ zinc stearate had an increase of $8.3 \%$ in this parameter, when compared to the neat blend. In general, the incorporation of stearates increased the crystallinity. 
Figure 8 - Peak melting temperature (a) and crystallinity (b) for 75PBAT/25PCL neat blend and containing $0.125 \%$ and $0.250 \%$ of zinc and magnesium stearates.
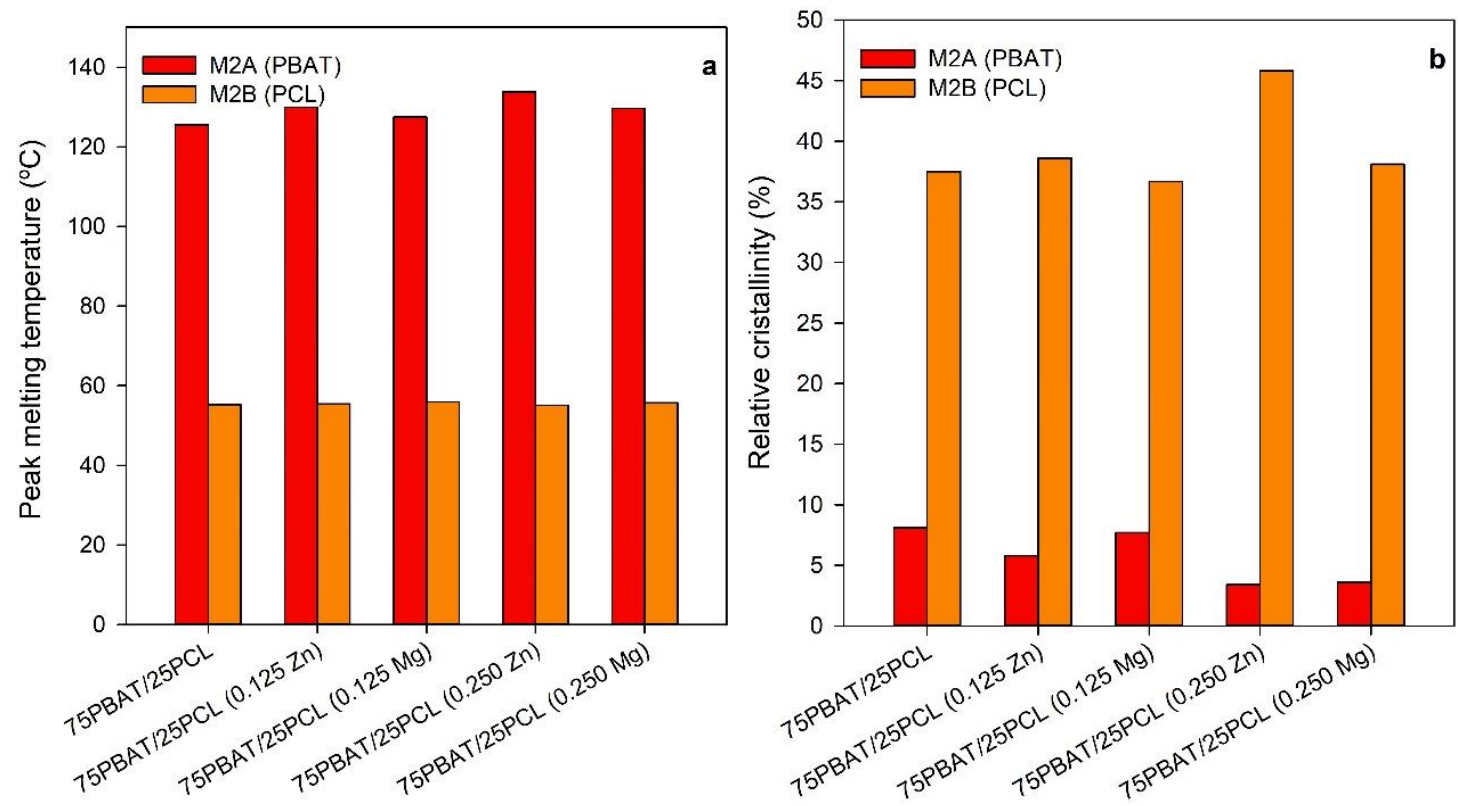

Source: Authors.

\subsection{Thermogravimetric Analysis (TGA)}

TG curves and parameters for all blends are shown in Figure 9 and Table 2.

Figure 9 - TG curves for 75PBAT/25PCL neat blend and those containing $0.125 \%$ and $0.250 \%$ of zinc and magnesium stearates.

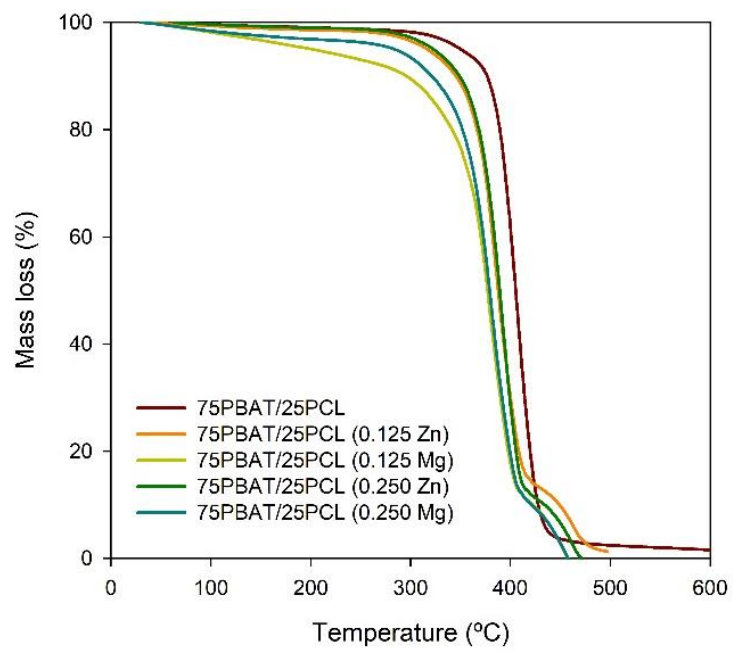

Source: Authors. 
Table 2 - Thermogravimetric data for 75PBAT/25PCL neat blend and those containing $0.125 \%$ and $0.250 \%$ of zinc and magnesium stearates.

\begin{tabular}{lc|c|c|c|c|c}
\hline \multicolumn{1}{c|}{ Sample } & $\mathrm{T}_{1}\left({ }^{\circ} \mathrm{C}\right)$ & $\mathrm{m}_{1}(\%)$ & $\mathrm{T}_{2}\left({ }^{\circ} \mathrm{C}\right)$ & $\mathrm{m}_{2}(\%)$ & $\mathrm{T}_{50 \%}\left({ }^{\circ} \mathrm{C}\right)$ & $\Delta \mathrm{m}$ \\
\hline 75PBAT/25PCL & 379.0 & 98.8 & 433.3 & 5.5 & 406.1 & 93.3 \\
75PBAT/25PCL $(0.125 \mathrm{Zn})$ & 359.4 & 99.3 & 407.8 & 12.7 & 383.6 & 86.6 \\
75PBAT/25PCL (0.125 Mg) & 342.6 & 99.6 & 401.9 & 11.9 & 372.2 & 87.7 \\
75PBAT/25PCL (0.250 Zn) & 359.9 & 99.6 & 409.5 & 11.5 & 384.7 & 88.1 \\
75PBAT/25PCL (0.250 Mg) & 345.3 & 99.7 & 406.2 & 7.8 & 375.7 & 91.9 \\
\hline
\end{tabular}

Source: Authors.

The mass loss observed in the TG curves of all samples occur in a single stage. For the neat blend, the mass loss occurs at a mean temperature of $406.1^{\circ} \mathrm{C}$, losing more than $90 \%$ of its mass between 379 and $433.3^{\circ} \mathrm{C}$. The thermal stability of blend is reduced with the incorporation of the stearates. Mean decreases in $\mathrm{T} 1 / 2$ of $23.8^{\circ} \mathrm{C}$ and $27.1^{\circ} \mathrm{C}$ for the blends with zinc and magnesium stearates, respectively, were observed and these appear to be dependent on stearated concentration as thermal stability decreases the higher the stearate content. Magnesium stearate showed greater catalytic oxidation effect. The pro-oxidant action of stearates tends to decreases the thermal stability of studied systems, corroborating the results obtained in mechanical properties and by DSC.

\subsection{Tensile Properties}

Tensile results for blends are shown in Figure 10. 
Figure 10 - Tensile modulus (a) and strength (b) and elongation at break (c) of 75PBAT/25PCL neat blend and containing 0.125\% and $0.250 \%$ of zinc and magnesium stearates.
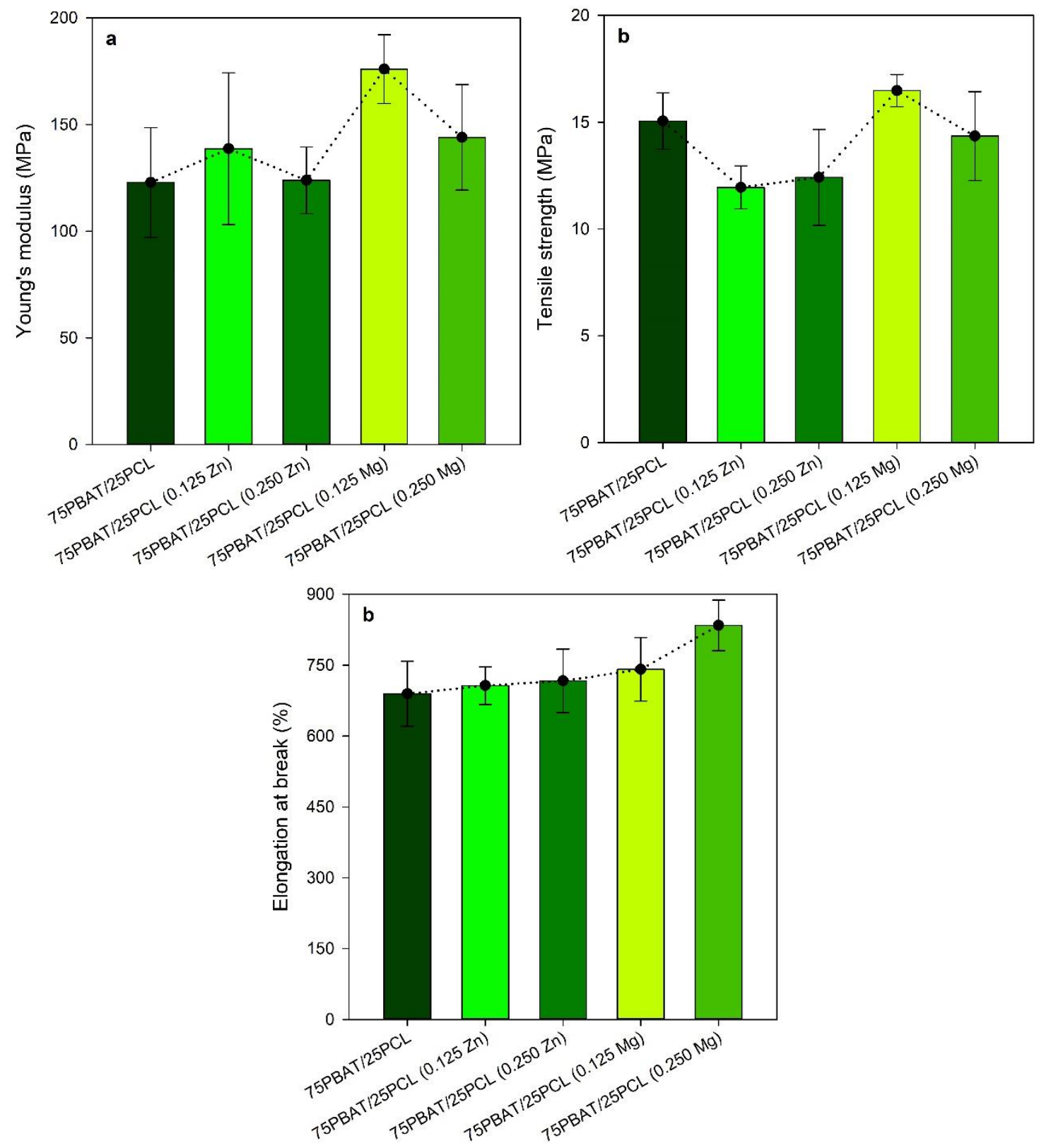

Source: Authors.

The results show that the mechanical properties of the films were affected by the presence and content of stearates. The incorporation of metallic stearates in the 75PBAT/25PCL blend caused increases in the modulus of the systems of up to $12.8 \%$ and $43.2 \%$, for the blend containing $0.125 \%$ of zinc and magnesium stearates, respectively. For blends containing $0.250 \%$ of zinc and magnesium stearates, the increase was $0.87 \%$ and $17.25 \%$, respectively. This indicates that the incorporation of metallic stearates stiffened the blend. Zinc stearate addition caused up to $20 \%$ reduction in tensile strength. Blends containing magnesium stearate displayed higher tensile strength values. The tensile strength of blend containing the lower $(0.125 \%)$ concentration of magnesium stearate increased $9.4 \%$ regarding to neat blend. This behavior is consistent with DSC results which showed that $0.125 \%$ magnesium stearate addition led to an increase in the crystallization temperature of PBAT and acted as nucleating agent, decreasing the size of the spherulite and thus improving the mechanical strength. Elongation at break increased in all cases, the effect of magnesium stearate being more evident. These results are attributed both to the increase in the free movement of 
polymer chains caused by the incorporation of lubricants, but also to their pro-oxidant effect, intensifying the thermal degradation of the systems, as observed in the rheometry and TGA data. Abrusci et al. (2011) and Ammala et al. (2011) reported that some stearates, especially cobalt, catalyze the thermo-oxidation of polyolefins. Similar results were obtained by Konduri et al. (2011) and Rosa et al. (2009).

\subsection{Scanning electron microscopy (SEM)}

The micrographs shown in Figure 11 refer to the fracture surface of the tensile specimens at 5000× magnification.

The 75PBAT/25PCL blends have a uniform and a pore-free structure. Some round particles dispersed on the matrix surface can be observed. It is believed that these particles result from condensation during cooling of the film in the chill-roll or incomplete melting of the blend components. Considering the PBAT and PCL melting temperatures, the processing temperatures employed and the small length of the extruder, it is possible that these are incompletely molten PBAT particles. The incorporation of stearates resulted in a morphology a little more homogeneous than the neat blend. It is believed that the acquired morphology is responsible for the reduction of mechanical properties discussed above. Similar results were obtained by Rosa et al. (2009).

Figure 11 - SEM images of fractured surface of samples. 75PBAT/25PCL neat blend (a), 75PBAT/25PCL (0.125 Zn) (b), 75PBAT/25PCL (0.125 Mg) (c), 75PBAT/25PCL (0.250 Zn) (d) and 75PBAT/25PCL (0.250 Mg) (e).
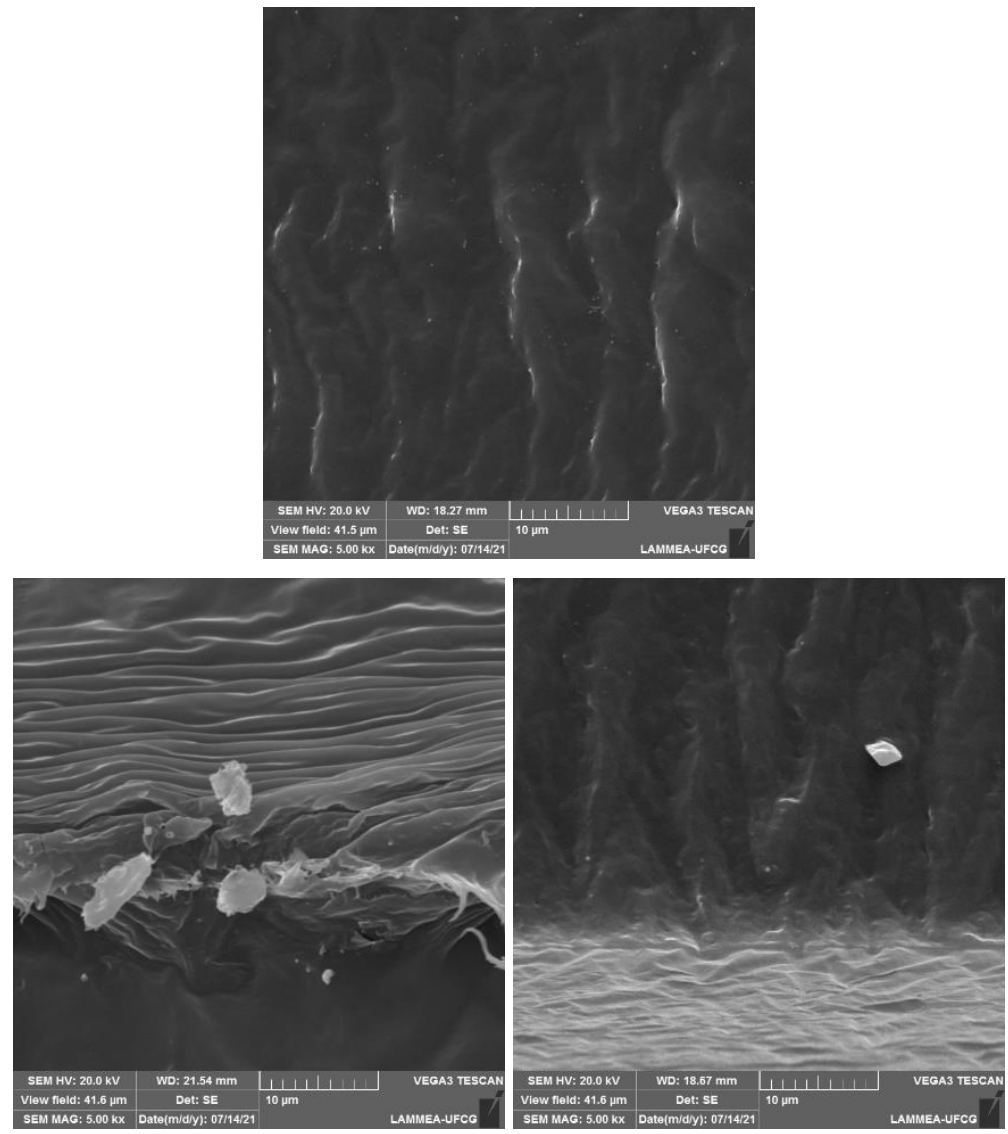


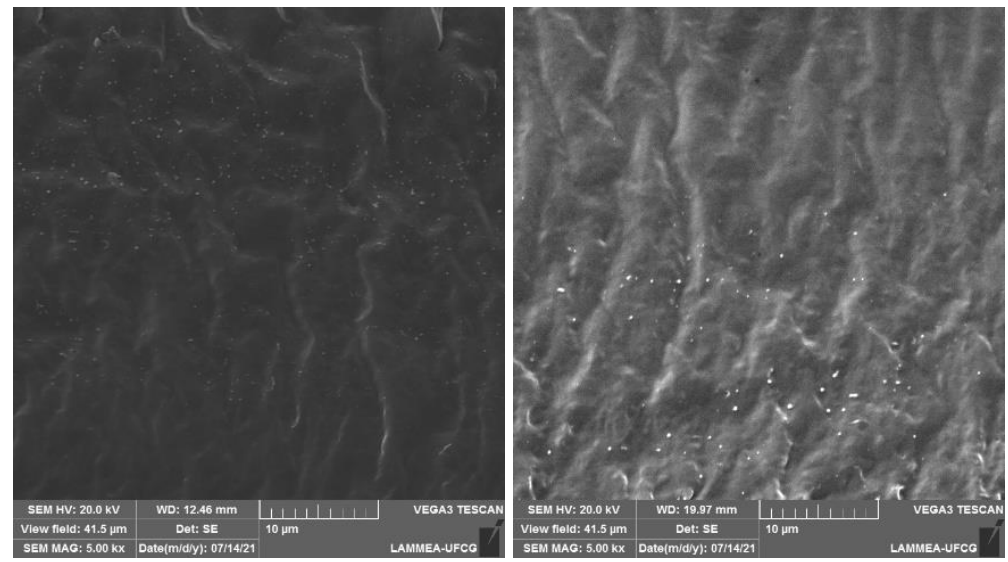

Source: Authors.

\section{Conclusion}

The results of this study indicate that the presence of zinc and magnesium stearates in 75PBAT/25PCL blend during processing in a torque rheometer do not prevent polymer degradation. The competition between the pro-degradant and lubricant effects of zinc and magnesium stearates can determine an optimal additive concentration for a balance between processing conditions and degradation. Adding up to $0.25 \%$ of magnesium stearate to 75PBAT/25PCL blend is a useful alternative of material that combines maintenance or improvement of properties combined with higher decomposition of these systems when arranged in environments under controlled conditions.

\section{Acknowledgments}

The authors thank to Federal University of Campina Grande (UFCG) for support and are grateful for the fellowships provided by Coordenação de Aperfeiçoamento de Pessoal de Nível Superior (CAPES) in favor of Sousa (PhD) and Conselho Nacional de Desenvolvimento Científco e Tecnológico (CNPq) in favor of Carvalho (PQ) and Almeida (PDJ\#160909/2019-8).

\section{References}

Abrusci, C., Pablos, J. L., Corrales, T., López-Marín, J., Marín, I. \& Catalina, F. (2011). Biodegradation of photo-degraded mulching films based on polyethylenes and stearates of calcium and iron as pro-oxidant additives. International Biodeterioration \& Biodegradation, 65, $451-459$.

Almeida, T. G., Silva Neto, J. E., Costa, A. R. M., Silva, A. S., Carvalho, L. H. \& Canedo, E. L. (2016). Degradation during processing in poly(butylene adipateco-terephthalate) /vegetable fiber compounds estimated by torque rheometry. Polymer Testing; 55, $204-211$.

Almeida, T. G. Compósitos de poli(butileno adipato-co-tereftalato) e fibra de babaçu: efeito do processamento e do tipo e teor de carga. (2019). Tese (Doutorado em Ciência e Engenharia de Materiais) - Universidade Federal de Campina Grande (UFCG).

Alves, T. S., Silva Neto, J. E., Silva, S. M. L., Carvalho, L. H. \& Canedo, E. L. (2016). Process simulation of laboratory internal mixers. Polymer Testing, 50, 94-100.

Ammala, A., Bateman, S., Dean, K., Petinakis, E., Sangwan, P., Wong, S., Yuan, Q., Yu, L., Patrick, C. \& Leong, K. H. (2011). An overview of degradable and biodegradable polyolefins. Progress in Polymer Science, 36, 1015-1049.

Antunes, M. C., Agnelli, J. A. M., Babetto, A. S., Bonse, B. C. \& Bettini, S. H. P. (2017) Abiotic thermo-oxidative degradation of high density polyethylene: Effect of manganese stearate concentration. Polymer Degradation and Stability, 143, 95-103.

Ayadi, F., Bliard, C. \& Dole, P. (2011). Materials based on maize biopolymers: Effect of flour components on mechanical and thermal behavior. Starch-Stärke, 604-615.

Bheemaneni, G., Saravana, S. \& Kandaswamy, R. (2018). Processing and characterization of Poly (butylenesadipate-co-terephtalate)/Wollastonite Biocomposites for Medical Applications. Materials Today: Proceedings. 5, 1807-1816.

Canedo, E. L. Processamento de Polímeros no Misturador Interno de Laboratório. 2a Edição. (2017). PPGCEMat-UFCG: Campina Grande, PB. [http://dx.doi.org/10.13140/RG.2.2.23644.64647]. 
Canedo, E. L. \& Alves, T. S. (2015) Processamento de Polímeros no Misturador Interno de Laboratório. Workshop CFD/UFCG, Campina Grande. https ://doi.org/10.13140/RG.2.1.1892.5921.

Cavalcante, M.P., Rodrigues, E. J. R. \& Tavares, M. I. N. (2015). Crystallinity evaluation of polyhydroxybutyrate and polycaprolactone blends.

Cesario, L.V., Morais, D, D.S., Bardi, M. A. G. \& Carvalho, L. H. (2018). Influência de estearatos metálicos nas propriedades do PBAT. Revista eletrônica de materiais e processos, 14, 184-189.

Cesario, L.V. Caracterização e degradação de filmes PBAT aditivados com estearatos metálicos. (2019). Dissertação (Mestrado em Engenharia de Materiais) Universidade Federal de Campina Grande (UFCG).

Costa, A. R. M., Almeida, T. G., Silva, S. M. L., Carvalho, L. H. \& Canedo, E. L. (2015). Chain extension in poly(butylene-adipate-terephthalate). Inline analysis in a laboratory internal mixer. Polymer Testing, 42, 115-121.

Duarte, I. S., Tavares, A. A., Lima, P. S., Andrade, D. L. A. C. S., Carvalho, L. H., Canedo, E. L. \& Silva, S. M. L. (2016). Chain extension of virgin and recycled poly(ethylene terephthalate): effect of processing conditions and reprocessing. Polymer Degradation and Stability, 124, $26-34$.

Godavitarne, C., Robertson, A., Peters, J. \& Rogers, B. Biodegradable materials. (2017) Orthopaedics and Trauma, 31, 316-320.

Gönen, M., Egbuchunam, T. O., Balköse, D., İnal, F. \& Ülkü, S. (2015). Preparation and characterization of magnesium stearate, cobalt stearate, and copper stearate and their effects on poly(vinyl chloride) dehydrochlorination. Journal of vinyl and additive technology, 21, 235-244.

Kijchavengkul, T., Auras, R., Rubino, M., Selke, S., Ngouajio, M. \& Fernandez, R. T. (2010) Biodegradation and hydrolysis rate of aliphatic aromatic polyester. Polymer Degradation and Stability; 95, 2641-2647.

Konduri, M. K. R., Koteswarareddy, G., Kumar, D. B. R., Reddy, B. V. \& Narasu, M. L. (2011). Effect of pro-oxidants on biodegradation of polyethylene (LDPE) by indigenous fungal isolate. Aspergillus oryzae. Journal of Applied Polymer Science;120, 3536-3545.

Marinho, V. A. D., Pereira, C. A. B., Vitorino, M. B. C., Silva, A. S., Carvalho, L. H. \& Canedo, E. L. (2017). Degradation and recovery in poly(butylene adipate-co-terephthalate)/thermoplastic starch blends. Polymer Testing, 58, 166-172.

Matta, A. K., Rao, R. U., Suman, K. N. S. \& Rambabu, V. (2014). Preparation and Characterization of Biodegradable PLA/PCL Polymeric Blends. Procedia Materials Science, 6, 1266-1270.

Miyata, T. \& Masuko, T. (1997). Morphology of poly (L-lactide) solution-grown crystals. Polymer, 38, 4003-4009.

Pagno, V., M’odenes, A. N., Dragunski, D. C., Fiorentin-Ferrari, L. D., Caetano, J., Guellis, C., Gonçalves, B. C., Anjos, E. V., Pagno, F. \& Martinelli, V. (2020). Heat treatment of polymeric PBAT/PCL membranes containing activated carbon from Brazil nutshell biomass obtained by electrospinning and applied in drug removal. Journal of Environmental Chemical Engineering; 8, 104159.

Reul, L. T. A., Pereira, C. A. B., Sousa, F. M., Santos, R. M., Carvalho, L. H. \& Canedo, E. L. (2018). Polycaprolactone/babassu compounds: rheological, thermal, and morphological characteristics. Polymer Composites, 40, S1, E540-E549.

Rosa, D. S., Grillo, D., Bardi, M. A. G., Calil, M. R., Guedes, C. G. F., Ramires, E. C. \& Frollini, E. (2009). Mechanical, thermal and morphological characterization of polypropylene/biodegradable polyester blends with additives. Polymer Testing, 28, 836-842.

Roy, P. K., Surekha, P., Rajagopal, C. \& Choudhary, V. (2006). Effect of cobalt carboxylates on the photo-oxidative degradation of low-density polyethylene. Part-I. Polymer Degradation and Stability, 91, 1980-1988.

Sousa, F. M., Costa, A. R. M., Reul, L. T. A., Cavalcanti, F. B., Carvalho, L. H., Almeida, T. G. \& Canedo, E. L. (2018). Rheological and thermal characterization of PCL/PBAT blends. Polymer Bulletin; 76,1573-1593.

Sousa, J. C., Carvalho, L. H., Almeida, Y. M. B. \& Canedo, E. L. (2016) Crystallization and melting of poly (butylene adipate terephtalate) in biocomposites with coconut fiber. In: 3rd Brazilian conference on composite materials (BCCM3), Gramado, RS.

Stuart, B. (2005). Infrared Spectroscopy: Fundamentals and Applications. Chichester: Willey.

Wu, C. (2012). Characterization of cellulose acetate-reinforced aliphatic-aromatic copolyester composites. Carbohydrate Polymers, 87, $1249-1256$.

Yang, B., Nar, M., Visi, D. K., Allen, M., Ayre, B., Webber, C. L., Lu, H. \& D’Souza, N. A. (2014). Effects of chemical versus enzymatic processing of kenaf fibers on poly(hydroxybutyrate-co-valerate)/poly(butylene adipate-co-terephthalate) composite properties. Composites Part B: Engineering, 56, 926-933. 